\title{
Vascular Smooth Muscle Cells Secrete CXCL10 in Response to Heat Shock Protein 90
}

\author{
Byung-Yong Rhim, Do-Hyung Kim and Koanhoi Kim*
}

Department of Pharmacology, School of Medicine, Pusan National University, Yangsan, Korea

Received March 19, 2011 /Accepted April 8, 2011

\begin{abstract}
Oxidative stress results in sustained release of heat shock protein 90 (HSP90) from vascular smooth muscle cells (VSMCs). We investigated whether extracellular HSP90 predisposed VSMCs to pro-inflammatory phenotype. Exposure of human aortic smooth muscle cells to HSP90 not only significantly enhanced CXCL10 secretion but also increased CXCL10 transcription. HSP90-mediated CXCL10 secretion was attenuated by OxPAPC, a TLR-2/4 inhibitor, and curcumin, a TLR- 4 dimerization inhibitor. Inhibitors of diphenyleneiodium chloride and the Akt pathway also attenuated CXCL10 secretion in response to HSP90. The gene delivery of IkB using recombinant adenoviruses and treatment with resveratrol, which inhibit NF-kB activity, significantly attenuated HSP90-induced CXCL10 secretion from VSMCs. We propose that extracellular HSP90 contributes to an inflammatory reaction in the stressed vasculature by inducing CXCL10 expression of VSMCs, and that TLR-4, Akt, and NF-kB play active roles in the process.
\end{abstract}

Key words : CXCL10, HSP90, vascular smooth muscle cells

\section{Introduction}

Heat shock proteins (HSPs) participate in protein folding and assembly and are crucial for correct transportation of proteins through the cell [21]. Among the families of HSPs grouped according to their molecular weight, HSP60 and HSP70 have been the subject of extensive studies with regard to immunogenic and inflammatory properties in association with atherosclerosis $[14,18]$. HSPs are normally intracellular, whereas HSP90 is secreted from vascular smooth muscle cells (VSMCs) during oxidative stress and from necrotic macrophages [2,7]. VSMCs reside mostly in the media of healthy arteries and regulate vascular tone. In atherosclerosis, VSMCs undergo phenotypic and cellular changes thought to be crucial in the development of atherosclerotic plaque, and thus producing cytokines and chemokines [8]. However, it is poorly defined whether the HSP90 affects VSMCs in terms of inflammatory property.

Chemokines are small proteins that induce chemotactic activity in various cells, especially cells of the immune system, and their target cells express appropriate chemokine receptors. Chemokines are classified into subfamilies, C, CC, CXC and CX3C chemokines, based on the spacing of their conserved cysteine motifs. For instance, the two N-terminal

*Corresponding author

Tel : +82-51-510-8064, Fax : +82-51-501-8068

E-mail : koanhoi@pusan.ac.kr cysteines of CXC chemokines are separated by one amino acid, represented with an X. CXC motif ligand 10 (CXCL10), which was also known as interferon (INF)-y-inducible protein $10 \mathrm{kDa}$ (IP-10), was initially identified as a chemokine induced by IFN- $\gamma$ and belongs to the CXC chemokine family. The chemokine is encoded by the CXCL10 gene in humans. It is secreted by various cell types, such as, monocytes, neutrophils, endothelial cells, keratinocytes, fibroblasts, mesenchymal cells, dendritic cells, and astrocytes [9]. CXCL10 is functionally categorized as an inflammatory chemokine. Moreover, CXCL10 lacking its ELR (glutamic acid-leucine-arginine) motif suppresses neovascularization and functions as an angiostatic chemokine [19].

CXCL10 binds to CXC chemokine receptor 3 (CXCR3), and regulates immune responses by activation and recruitment of leukocytes, such as, T cells, eosinophils, monocytes, and natural killer (NK) cells [6,20]. CXCR3 is expressed not only by immune cells, but also by resident cells such as endothelial cells, vascular pericytes and mesangial cells. Three CXCR3 binding ligands are known, namely, CXC motif ligand 9 (CXCL9), CXCL10, and CXC motif ligand 11 (CXCL11). Recent reports have shown that the serum and/or the tissue expressions of CXCL10 are increased in various autoimmune diseases like rheumatoid arthritis, systemic lupus erythematosus, systemic sclerosis, multiple sclerosis, autoimmune thyroid diseases, type 1 diabetes mellitus and 
Addison's disease [3,4,12,15,17], and CXCL10 and CXCR3 may have important roles in leukocyte homing to inflamed tissues and in the perpetuation of inflammation, and thus, may importantly contribute to tissue damage.

To explore the potential role of secreted HSP90 in vascular inflammation, we investigated whether extracellular HSP90 induced CXCL10 in VSMCs and found that aortic smooth muscle cells (AoSMCs) exhibited up-regulation of CXCL10 in response to HSP90. Furthermore, we identified cellular factors associated with HSP90-induced CXCL10 up-regulation in VSMCs.

\section{Materials and Methods}

\section{Cell culture and reagents}

Human AoSMCs purchased from American Type Culture Collection (ATCC, Manassas, VA, USA) were grown in ATCC-formulated F-12K Medium (ATCC) supplemented with Vascular Smooth Muscle Growth Kit, 50 units/ml penicillin and $50 \mu \mathrm{g} / \mathrm{ml}$ streptomycin in humidified atmosphere of $5 \% \mathrm{CO}_{2}$. The cells in between passage 6 and 9 were used. Recombinant HSP90 was purchased from ProSpec-Tany Technogene Ltd (Rehovot, Israel). Akti IV, an Akt inhibitor, was purchased from Santa Cruz Biotechnology (Santa Cruz, CA, USA). Oxidized 1-palmitoyl-2- arachidonosyl-sn-phosphatidylcholine (OxPAPC) was purchased from Invivogen (San Diego, CA, USA). Resveratrol (3,4',5-trihydroxy-transstilbene), LY294002, curcumin, N-acetylcysteine (NAC) and diphenyleneiodium chloride (DPI) were purchased from Sigma-Aldrich Co. (St. Louis, MO, USA).

\section{Enzyme linked immunosorbent assay (ELISA) of CXCL10}

The amount of CXCL10 released from the cells into the culture medium was determined using a commercially available ELISA kit according to the manufacturer's instructions (BD Biosciences, San Diego, CA). Cells were serum-starved for $6 \mathrm{hr}$ and exposed to HSP90 prior to isolation of the culture medium. The isolated culture medium and CXCL10 standards were added to a plate pre-coated with a monoclonal antibody against CXCL10. After incubation for an hour, the plate was washed and incubated with an enzyme-linked polyclonal antibody specific for CXCL10. After several washes, the substrate solution was added, and the color intensity was determined.
Reverse transcription (RT) - polymerase chain reaction (PCR)

Total RNAs extracted from VSMCs were reverse-transcribed for $1 \mathrm{~h}$ at $42^{\circ} \mathrm{C}$ with Moloney Murine Leukemia Virus reverse transcriptase, followed by PCR analysis. For PCR analysis, primers for CCL2 were 5'-TCTGTGCC TGCTGCT CATAG-3' (forward) and 5'-CAGATCTCCTTG GCCACAAT-3' (reverse). Primers for CXCL10 were 5'-CCATTCTGATTTGCTGCCTTA-3' (forward) and 5'TTCTTGATGGCCTTCGATTC-3' (reverse). Primers for glyceraldehyde dehydrogenase (GAPDH) were 5'-GAGTCA ACGGATTTGGTCGT-3' (forward) and 5'-TGTGGTCA TGAGTCCTTCCA-3' (reverse). PCR products were size-separated by electrophoresis on $2 \%$ agarose gels and visualized after staining with ethidium bromide.

\section{Construction of recombinant adenoviruses}

Recombinant adenoviral DNAs were prepared via homologous recombination in E. coli, in accordance with AdEasy Adenoviral vector system (Stratagene, La Jolla, CA, USA). The transactivation domain deletion mutant of c-Jun (TAM-67), $\beta$-galactosidase and the hemagglutinin-tagged inhibitor of nuclear factor kappa B (IкB) (32A/36A) were cloned into the Shuttle vector and transfected with the pAdEasy-1 vector into E. coli BJ5183. Recombinant adenoviral DNAs were transfected into 293 cells and replication deficient recombinant adenoviruses were generated. Adenoviruses containing genes of interest were isolated using a commercially available Virapur adenovirus purification kit (VIRAPUR, San Diego, CA) following manufacturer's instructions. Purified viruses were aliquoted and stored at $-80^{\circ} \mathrm{C}$.

\section{Statistics}

Statistical analyses were performed by ANOVA, and $p<0.05$ was considered statistically significant.

\section{Results}

Up-regulation of CXCL10 expression by HSP90 in VSMCs In order to investigate the effects of HSP90 on CXCL10 expression in VSMCs, we examined levels of CXCL10 transcripts by RT-PCR after exposure of human AoSMCs to recombinant HSP90. HSP90 elevated CXCL10 transcript in proportion to incubation period (Fig. 1A). The elevation of CXCL10 transcript was observed as early as $6 \mathrm{hr}$ post-treat- 
(A)

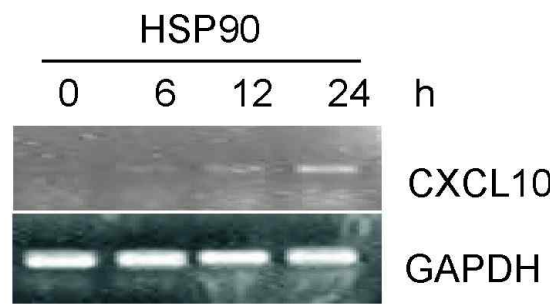

(B)

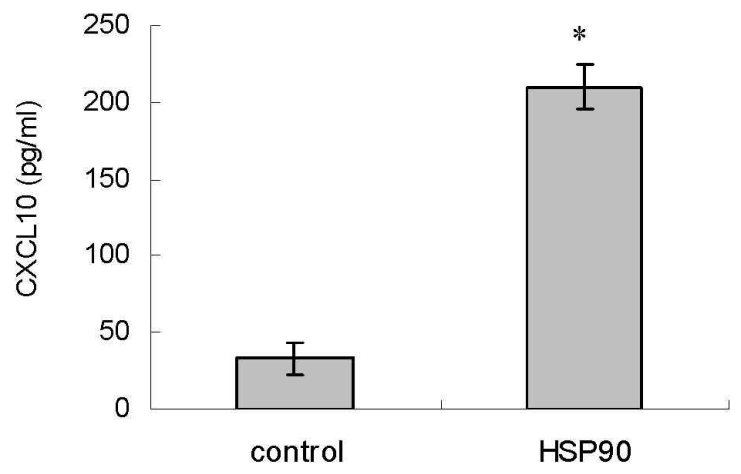

Fig. 1. The effects of HSP90 on CXCL10 at the transcript and protein levels. (A) Human AoSMCs were treated for the indicated time periods with $100 \mathrm{ng} / \mathrm{ml}$ of HSP90, and CXCL10 transcript was amplified by RT-PCR. PCR products were separated on an agarose gel prior to visualization. (B) Human AoSMCs $\left(1 \times 10^{6}\right.$ cells) cultured in growth media were incubated for $24 \mathrm{hr}$ in the presence of HSP90 $(100 \mathrm{ng} / \mathrm{ml})$ or bovine serum albumin (BSA) (control). Culture media were harvested, and CXCL10 secreted into the culture medium was measured using ELISA. Data are expressed as mean $\pm \mathrm{SD}(\mathrm{n}=3$ replicates/group). * $p<0.001$ vs. control.

ment and persisted up to $24 \mathrm{hr}$ post-treatment. We also investigated whether HSP90 had any effect on CXCL10 secretion. Human AoSMCs secreted CXCL10 in response to HSP90, as determined by ELISA (Fig. 1B). The amount of CXCL10 in the medium increased from $34 \mathrm{pg} / \mathrm{ml}$ to 210 $\mathrm{pg} / \mathrm{ml}$ in the presence of HSP90.

Involvement of Toll-like receptor (TLR) pathways in CXCL10 expression

We investigated whether HSP90-induced CXCL10 expression was influenced by chemicals known to modify TLR signaling. The amount of CXCL10 secreted to culture medium was determined by ELISA, after human AoSMCs were treated with HSP90 in the presence of OxPAPC, curcumin,
(A)

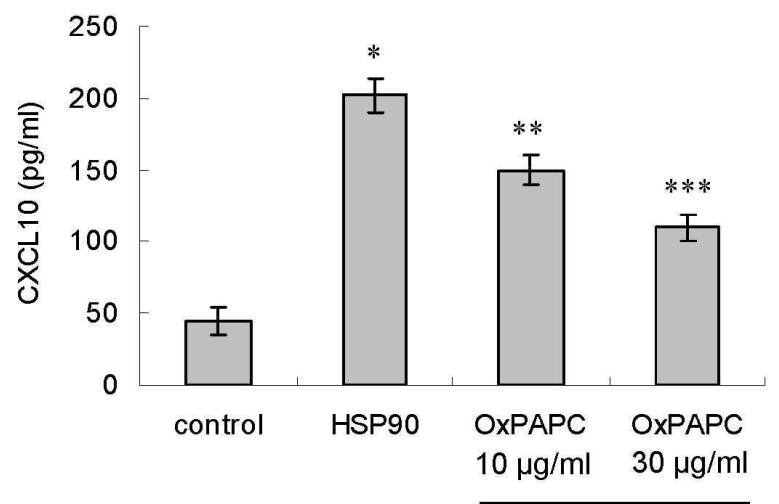

(B)

HSP90

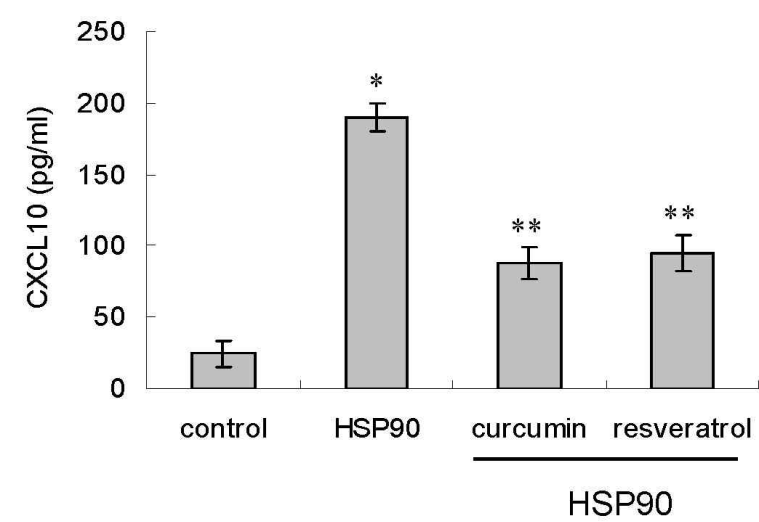

Fig. 2. The effects of TLR inhibitors on CXCL10 secretion. (A) Human AoSMCs were pre-incubated with indicated concentration of OxPAPC and stimulated for $24 \mathrm{hr}$ with HSP90. The amount of CXCL10 secreted into the culture medium was measured by ELISA. Data are expressed as mean $\pm \mathrm{SD}(\mathrm{n}=3$ replicates/group). * $p<0.001$ vs. control. ${ }^{* *} p<0.05$ vs. HSP90. ${ }^{* * *} p<0.01$ vs. HSP90. (B) Human AoSMCs were pre-incubated with curcumin (10 $\mu \mathrm{M})$ or resveratrol $(30 \mu \mathrm{M})$ and stimulated for $24 \mathrm{hr}$ with HSP90. The amount of CXCL10 secreted into the culture medium was measured by ELISA. Data are expressed as mean $\pm \mathrm{SD}\left(\mathrm{n}=3\right.$ replicates/group). ${ }^{*} p<0.001$ vs. control. ${ }^{* *} p<0.01$ vs. HSP90.

and resveratrol. All 3 chemicals significantly attenuated HSP90-mediated CXCL10 secretion (Fig. 2A). CXC10 secretion from AoSMCs was increased to $200 \mathrm{pg} / \mathrm{ml}$ in response to HSP90, which was reduced to $110 \mathrm{pg} / \mathrm{ml}$ in the presence of OxPAPC, an inhibitor of TLR2/4, at the final concentration of $30 \mu \mathrm{M}$. Curcumin and resveratrol also profoundly suppressed CXCL10 secretion (Fig. 2B). Secretion of CXCL10 from AoSMCs increased to $190 \mathrm{pg} / \mathrm{ml}$ in response to HSP90, which was reduced to 88 and $95 \mathrm{pg} / \mathrm{ml}$ in the presence of 
curcumin and resveratrol, respectively.

Role of Akt pathway in HSP90-induced CXCL10 secretion

To investigate the roles of Akt pathway in CXCL10 expression, we used two inhibitors, LY294002 and Akti IV. The amount of CXCL10 secreted to culture medium was determined, after human AoSMCs were treated with HSP90 in the presence of LY294002 or Akti IV. Akti IV and LY294002, an inhibitor of phosphatidylinositol 3-kinase (PI3K) which activate Akt, almost completely blocked HSP90-induced CXCL10 secretion (Fig. 3). The amount of CXCL10 secreted from AoSMCs increased to $230 \mathrm{pg} / \mathrm{ml}$ in response to HSP90, and it was reduced to the background level pre-treatment with LY294002 or Akti IV.

Roles of reactive oxygen species (ROS) in HSP90-induced expression of CXCL10

We examined the effects of the two ROS quenchers, NAC and DPI, on CXCL10 secretion to understand the roles of ROS in CXCL10 expression. The amount of CXCL10 secreted to culture medium was determined, after human AoSMCs were treated with HSP90 in the presence of NAC or DPI. DPI, but not NAC, significantly attenuated HSP90-induced CXCL10 secretion (Fig. 4). Secretion of CXCL10 from AoSMCs increased to $220 \mathrm{pg} / \mathrm{ml}$ in response to HSP90, which were reduced to $150 \mathrm{pg} / \mathrm{ml}$ by pre-treatment with DPI.

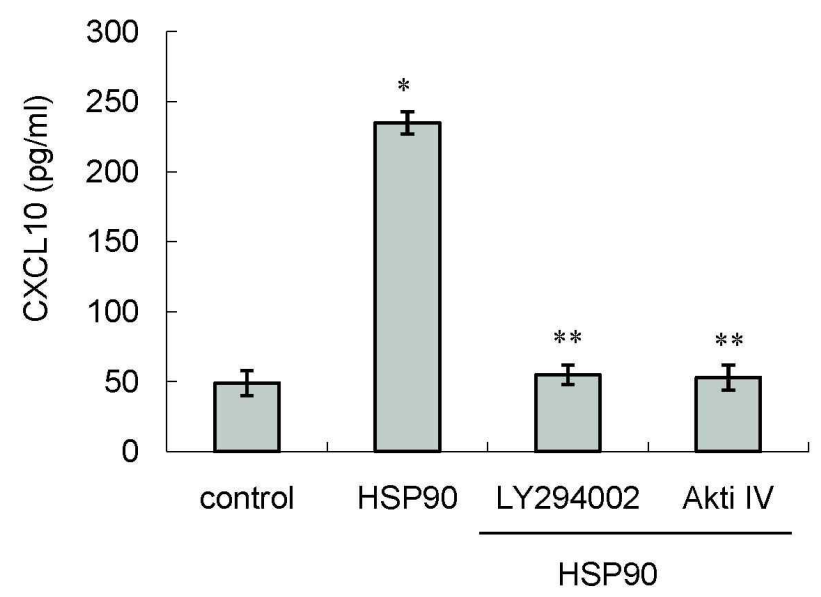

Fig. 3. The effects of inhibitors of Akt pathway on CXCL10 secretion. Human AoSMCs were pre-incubated with LY294002 or Akti IV (10 $\mu \mathrm{M}$ each) and stimulated for $24 \mathrm{hr}$ with HSP90. The amount of CXCL10 secreted into the culture medium was measured by ELISA. Data are expressed as mean $\pm \mathrm{SD}$ ( $\mathrm{n}=3$ replicates/group). ${ }^{*} p<0.001$ vs. control. ${ }^{* *} p<0.001$ vs. HSP90.

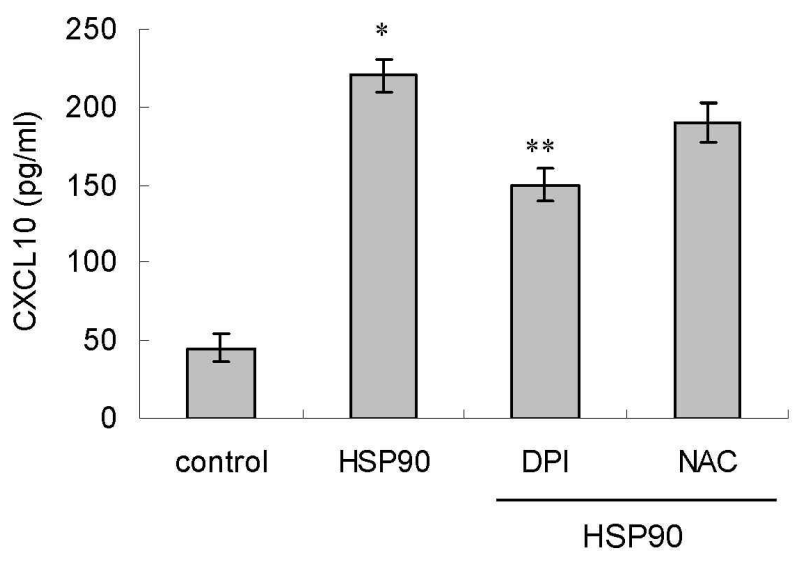

Fig. 4. The effects of ROS quenchers on CXCL10 secretion. Human AoSMCs were pre-incubated with DPI $(10 \mu \mathrm{M})$ or NAC $(5 \mathrm{mM})$ and stimulated for $24 \mathrm{hr}$ with HSP90. The amount of CXCL10 secreted into the culture medium was measured by ELISA. Data are expressed as mean \pm SD ( $\mathrm{n}=3$ replicates/group). ${ }^{*} p<0.001$ vs. control. ** $p<0.05$ vs. HSP90.

\section{Role of $N F-k B$ in HSP90-induced CXCL10} secretion

We examined the effects of transcription factor nuclear factor kappa B (NF-kB) and c-Jun on HSP90-mediated CXCL10 secretion using adenoviruses expressing endogenous inhibitor of NF- $\mathrm{kB}$ and dominant negative form c-Jun. Human AoSMCs were infected with recombinant adenoviruses expressing $\beta$-galactosidase, inhibitor kappa B (Ik B), or transactivation domain deletion mutant of c-Jun (TAM-67) and exposed to HSP90. HSP90-mediated CXCL10 secretion was significantly attenuated by IkB, but not by TAM-67 (Fig. 5).

\section{Discussion}

Expression of cytokine or chemokine in vasculature contributes to vascular diseases. It is believed that cytokineand chemokine-mediated inflammatory and immune process including immigration and infiltration of leukocytes, macrophages and $\mathrm{T}$ cells into and activation of them within the artery leads to progression of atherosclerosis and plaque instability. The specialized roles of cytokines or chemokines in atherosclerosis are well documented $[8,26]$. Owing to active participation of chemokine in atherogenesis, the identification and characterization of the factors regulating chemokine expression are important and will lead us to new insights into strategies for the prevention and therapy of atherosclerosis. We focused on expression of CXCL10 in re- 


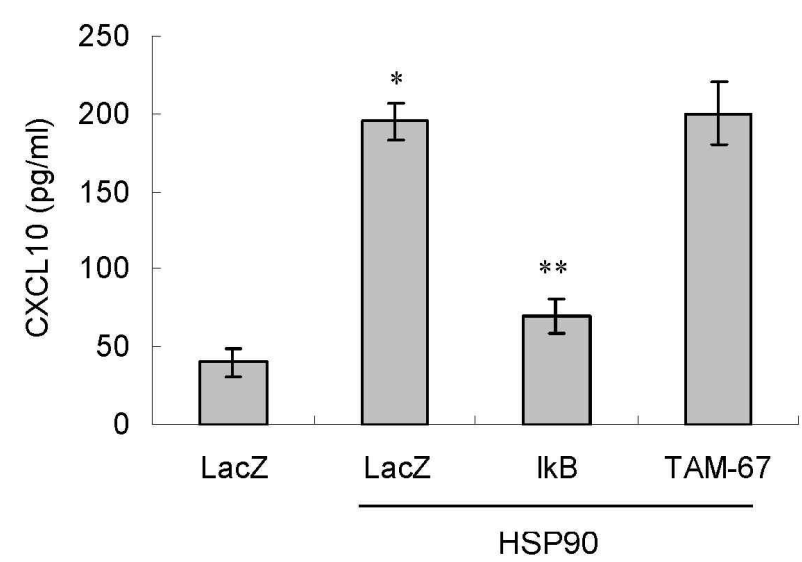

Fig. 5. The effect of IkB on CXCL10 secretion. Human AoSMCs were infected with recombinant adenoviruses overexpressing $\beta$-galactosidase (LacZ), IkB, or dominant negative c-Jun (TAM-67) and stimulated with HSP90. The amount of CXCL10 secreted into the culture medium was measured by ELISA. Data are expressed as mean $\pm \mathrm{SD}$ ( $\mathrm{n}=3$ replicates/group). ${ }^{*} p<0.001$ vs. control. ** $p<0.01$ vs. HSP90.

sponse to extracellular HSP90 and regulatory molecules involved in CXCL10 expression in VSMCs. We found that when human AoSMCs were exposed to HSP90, CXCL10 transcript was significantly increased, and secretion of CXCL10 protein from VSMCs was elevated. These data indicate that HSP90 up-regulates the chemokine at transcriptional and post-translational levels.

Arterial SMCs of both humans and mice acquire proinflammatory and proliferative phenotypes in response to relevant pathogenic stimuli via pathways involving activation of particular subtypes of TLRs [22,23]. Therefore, it was investigated whether TLRs played a role in expression of CXCL10 by HSP90. OxPAPC, an inhibitor of TLR2/4, inhibited CXCL10 expression induced by HSP90. Among the subtypes of TLRs, TLR-4 seems to be closely associated with atherosclerosis, as knockout of TLR-4 or its adaptor molecule, myeloid differentiation primary response protein 88 (MyD88), has been reported to block inflammatory response and proliferation of VSMCs in the atherosclerotic lesion $[5,11]$. To support the idea that TLR-4 plays a primary role in response to HSP90, curcumin and resveratrol were employed. Curcumin inhibits ligand-induced and ligand-independent dimerization of TLR-4, and thus inhibits both MyD88- and TIR-domain-containing adapter-inducing interferon- $\beta$ (TRIF)-dependent pathways in lipopolysaccharideinduced TLR-4 signaling [16,25]. Resveratrol inhibits NF- $\kappa B$ activation induced by TRIF [24]. Curcumin and resveratrol inhibited up-regulation of CXCL10 protein induced by HSP90. Moreover, CXCL10 induction was suppressed by ROS inhibition with DPI, a NADPH oxidase inhibitor, and by biological inhibitor of NF- $\mathrm{kB}$. These results are consistent with the fact that ROS and NF- $\kappa B$ play roles in TLR-4 signaling $[1,13]$. Taken together, these findings indicate active involvement of TLR-4 and its downstream molecules in CXCL10 induction in response to HSP90.

PI3K modifies the inner leaflet of the plasma membrane to provide attachment sites for signaling proteins and can activate Akt [10]. The present study showed that inhibitors of PI3K and Akt inhibited HSP90-mediated up-regulation of CXCL10. These results indicate that certain type of G protein and its signaling molecules such as $\mathrm{PI} 3 \mathrm{~K}$ and Akt, play major roles in HSP90-mediated expression of CXCL10 in human VSMC.

We demonstrated that extracellular HSP90 induced CXCL10 expression in VSMCs via TLR signaling pathway. These findings suggest that HSP90, which is secreted by oxidative stress and during necrotic cell death, would upregulate CXCL10 in VSMCs through TLR, and thereby would contribute to the inflammatory reaction in the damaged vasculature.

\section{Acknowledgement}

This work was supported for two years by Pusan National University Research Grant (B-Y, Rhim).

\section{References}

1. Akira, S. and K. Takeda. 2004. Toll-like receptor signalling. Nat. Rev. Immunol. 4, 499-511.

2. Basu, S., R. J. Binder, R. Suto, K. M. Anderson, and P. K. Srivastava. 2000. Necrotic but not apoptotic cell death releases heat shock proteins, which deliver a partial maturation signal to dendritic cells and activate the NF-kappa B pathway. Int. Immunol. 12, 1539-1546.

3. Fujii, H., Y. Shimada, M. Hasegawa, K. Takehara, and S. Sato. 2004. Serum levels of a Th1 chemoattractant IP-10 and Th2 chemoattractants, TARC and MDC, are elevated in patients with systemic sclerosis. J. Dermatol. Sci. 35, 43-51.

4. Hanaoka, R., T. Kasama, M. Muramatsu, N. Yajima, F. Shiozawa, Y. Miwa, M. Negishi, H. Ide, H. Miyaoka, H. Uchida, and M. Adachi. 2003. A novel mechanism for the regulation of IFN-gamma inducible protein-10 expression in rheumatoid arthritis. Arthritis Res. Ther. 5, R74-81.

5. Hollestelle, S. C., M. R. De Vries, J. K. Van Keulen, A. H. Schoneveld, A. Vink, C. F. Strijder, B. J. Van Middelaar, G. 
Pasterkamp, P. H. Quax, and D. P. De Kleijn. 2004. Toll-like receptor 4 is involved in outward arterial remodeling. Circulation 109, 393-398.

6. Jinquan, T., C. Jing, H. H. Jacobi, C. M. Reimert, A. Millner, S. Quan, J. B. Hansen, S. Dissing, H. J. Malling, P. S. Skov, and L. K. Poulsen. 2000. CXCR3 expression and activation of eosinophils: role of IFN-gamma-inducible protein-10 and monokine induced by IFN-gamma. J. Immunol. 165, 1548-1556

7. Liao, D. F., Z. G. Jin, A. S. Baas, G. Daum, S. P. Gygi, R. Aebersold, and B. C. Berk. 2000. Purification and identification of secreted oxidative stress-induced factors from vascular smooth muscle cells. J. Biol. Chem 275, 189-196.

8. Libby, P. 2002. Inflammation in atherosclerosis. Nature 420, 868-874.

9. Luster, A. D. and J. V. Ravetch. 1987. Biochemical characterization of a gamma interferon-inducible cytokine (IP-10). J. Exp. Med 166, 1084-1097.

10. Manning, B. D. and L. C. Cantley. 2007. AKT/PKB signaling: navigating downstream. Cell 129, 1261-1274.

11. Michelsen, K. S., M. H. Wong, P. K. Shah, W. Zhang, J. Yano, T. M. Doherty, S. Akira, T. B. Rajavashisth, and M. Arditi. 2004. Lack of Toll-like receptor 4 or myeloid differentiation factor 88 reduces atherosclerosis and alters plaque phenotype in mice deficient in apolipoprotein E. Proc. Natl. Acad Sci. USA 101, 10679-10684.

12. Narumi, S., T. Takeuchi, Y. Kobayashi, and K. Konishi. 2000. Serum levels of interferon-inducible PROTEIN-10 relating to the activity of systemic lupus erythematosus. Cytokine 12, 1561-1565.

13. Park, H. S., H. Y. Jung, E. Y. Park, J. Kim, W. J. Lee, and Y. S. Bae. 2004. Cutting edge: direct interaction of TLR4 with $\mathrm{NAD}(\mathrm{P}) \mathrm{H}$ oxidase 4 isozyme is essential for lipopolysaccharide-induced production of reactive oxygen species and activation of NF-kappa B. J. Immunol. 173, 3589-3593.

14. Pockley, A. G. 2003. Heat shock proteins as regulators of the immune response. Lancet 362, 469-476.

15. Rotondi, M., L. Chiovato, S. Romagnani, M. Serio, and P. Romagnani. 2007. Role of chemokines in endocrine autoimmune diseases. Endocr. Rev. 28, 492-520.

16. Singh, S. and B. B. Aggarwal. 1995. Activation of transcription factor NF-kappa B is suppressed by curcumin (diferuloylmethane). J. Biol. Chem 270, 24995-25000.
17. Sorensen, T. L., M. Tani, J. Jensen, V. Pierce, C. Lucchinetti, V. A. Folcik, S. Qin, J. Rottman, F. Sellebjerg, R. M. Strieter, J. L. Frederiksen, and R. M. Ransohoff. 1999. Expression of specific chemokines and chemokine receptors in the central nervous system of multiple sclerosis patients. J. Clin. Invest. 103, 807-815.

18. Srivastava, P. 2002. Roles of heat-shock proteins in innate and adaptive immunity. Nat. Rev. Immunol. 2, 185-194.

19. Strieter, R. M., P. J. Polverini, S. L. Kunkel, D. A. Arenberg, M. D. Burdick, J. Kasper, J. Dzuiba, J. Van Damme, A. Walz, D. Marriott, and et al. 1995. The functional role of the ELR motif in CXC chemokine-mediated angiogenesis. J. Biol. Chem 270, 27348-27357.

20. Taub, D. D., A. R. Lloyd, K. Conlon, J. M. Wang, J. R. Ortaldo, A. Harada, K. Matsushima, D. J. Kelvin, and J. J. Oppenheim. 1993. Recombinant human interferon-inducible protein 10 is a chemoattractant for human monocytes and $\mathrm{T}$ lymphocytes and promotes $\mathrm{T}$ cell adhesion to endothelial cells. J. Exp. Med 177, 1809-1814.

21. Whitley, D., S. P. Goldberg, and W. D. Jordan. 1999. Heat shock proteins: a review of the molecular chaperones. $J$. Vasc. Surg. 29, 748-751.

22. Yang, X., D. Coriolan, V. Murthy, K. Schultz, D. T. Golenbock, and D. Beasley. 2005. Proinflammatory phenotype of vascular smooth muscle cells: role of efficient Toll-like receptor 4 signaling. Am J. Physiol. Heart Circ. Physiol. 289, H1069-1076.

23. Yang, X., D. Coriolan, K. Schultz, D. T. Golenbock, and D. Beasley. 2005. Toll-like receptor 2 mediates persistent chemokine release by Chlamydia pneumoniae-infected vascular smooth muscle cells. Arterioscler. Thromb. Vasc. Biol. 25, 2308-2314.

24. Youn, H. S., J. Y. Lee, K. A. Fitzgerald, H. A. Young, S. Akira, and D. H. Hwang. 2005. Specific inhibition of MyD88-independent signaling pathways of TLR3 and TLR4 by resveratrol: molecular targets are TBK1 and RIP1 in TRIF complex. J. Immunol. 175, 3339-3346.

25. Youn, H. S., S. I. Saitoh, K. Miyake, and D. H. Hwang. 2006. Inhibition of homodimerization of Toll-like receptor 4 by curcumin. Biochem Pharmacol. 72, 62-69.

26. Zernecke, A., E. Shagdarsuren, and C. Weber. 2008. Chemokines in atherosclerosis: an update. Arterioscler. Thromb. Vasc. Biol. 28, 1897-1908. 
초록 : 혈관평활근세포에서 HSP90에 의한 CXCL10 증가에 관여하는 인자에 대한 연구

임병용·김도형·김관회*

(부산대학교 의학전문대학원 약리학교실)

Heat shock protein (HSP)은 외부적인 자극에 반응하여 세포를 보호하는 역할을 한다. 또한 HSP90은 혈관질환 에서 처럼 세포가 사멸되거나 손상을 입는 경우 세포 밖으로 유리된다. 그러나 지금까지 세포 밖 HSP90이 혈관 평활근세포에 어떠한 영향을 주는지에 대한 연구는 미약하다. 따라서 본 연구는 혈관평활근세포에서 HSP90이 CXCL10 발현에 대한 영향과 그 기전을 규명하였다. HSP90에 노출된 혈관평활근세포에서 CXCL10 transcript가 증가하고, CXCL10 단백질의 분비가 증가되었다. HSP90에 의한 CXCL10 분비는 Toll-like receptor (TLR)-2/-4 억 제제인 1-palmitoyl-2-arachidonosyl-sn-phosphatidylcholine (OxPAPC)과 NADPH oxidase 억제제인 diphenyleneiodium 그리고 Akt 경로를 억제하는 LY294002와 Akti IV에 의하여 크게 감소되었다. 또한 TLR-4의 dimerization을 저해하는 curcumin 역시 HSP90에 의한 CXCL10의 분비를 억제하였다. 전사인자인 nuclear factor kappa $\mathrm{B}(\mathrm{NF}-\mathrm{kB}$ )의 생물학적 억제제인 inhibitory kappa B (IkB)와 NF-kB 억제작용이 있는 rasveratrol은 HSP90에 의한 CXCL10 분비를 억제하였다. 이러한 결과는 혈관평활근세포에서 HSP90에 의한 CXCL10의 발현에 TLR-4와 Akt 및 NF-kB가 관여함을 의미한다. 